\title{
Microbial Pathogens in Source and Treated Waters from Drinking Water Treatment Plants in the United States and Implications for Human Health
}

Dawn N. King, ${ }^{1, \dagger}$ Maura Donohue, ${ }^{1, \dagger}$ Stephen J. Vesper, ${ }^{1, \dagger}$ Eric N.Villegas, ${ }^{1, \dagger}$ Michael W. Ware, ${ }^{1, \dagger}$ Megan E.Vogel, ${ }^{\ddagger}$ Edward F. Furlong, ${ }^{\S}$ Dana W. Kolpin, ${ }^{\|}$Susan T. Glassmeyer ${ }^{\dagger}$, and Stacy Pfaller ${ }^{1, \dagger * *}$

$\dagger^{\dagger}$ Office of Research and Development, National Exposure Research Laboratory, United States Environmental Protection Agency, 26 West Martin Luther King Dr., Cincinnati, OH 45268, United States

Department of Internal Medicine, University of Cincinnati, College of Medicine, 231 Albert Sabin Way, Cincinnati, OH 45229, United States

${ }^{\S}$ U.S. Geological Survey, Denver Federal Center, P.O. Box 25585, Denver, Colorado 80225, United States

"U.S. Geological Survey, 400 S. Clinton Street, Iowa City, Iowa 52240, United States

${ }^{1}$ These authors contributed equally to this research.

*Address correspondence, pfaller.stacy@epa.gov; Phone: +1 (513) 569-7983; fax: +1 (513) 5697017

(C) 2016. This manuscript version is made available under the Elsevier user license http://www.elsevier.com/open-access/userlicense/1.0/ 


\section{ABSTRACT}

An occurrence survey was conducted on selected pathogens in source and treated drinking water collected from 25 drinking water treatment plants (DWTPs) in the United States. Water samples were analyzed for the protozoa Giardia and Cryptosporidium (EPA Method 1623); the fungi Aspergillus fumigatus, A. niger and A. terreus (quantitative PCR [qPCR]); and the bacteria Legionella pneumophila (qPCR), Mycobacterium avium, M. avium subspecies paratuberculosis, and M. intracellulare (qPCR and culture). Cryptosporidium and Giardia were detected in $25 \%$ and in $46 \%$ of the source water samples, respectively (treated waters were not tested). Aspergillus fumigatus was the most commonly detected fungus in source waters (48\%) but none of the three fungi were detected in treated water. L. pneumophila was detected in $25 \%$ of the source water samples but in only $4 \%$ of treated water samples. M. avium and $M$. intracellulare were both detected in $25 \%$ of source water, while all three mycobacteria were detected in $36 \%$ of treated water samples. Five species of mycobacteria, M. mucogenicum, M. phocaicum, M. triplex, M. fortuitum, and M. lentiflavum were cultured from treated water samples. Although these DWTPs represent a fraction of those in the U.S., the results suggest that many of these pathogens are widespread in source waters but that treatment is generally effective in reducing them to below detection limits. The one exception is the mycobacteria, which were commonly detected in treated water, even when not detected in source waters.

Keywords: pathogens, drinking water, treatment, source water, occurrence 


\subsection{INTRODUCTION}

The advent of disinfection and centralized treatment has had a major impact on reducing outbreaks of disease caused by contaminated drinking water, though illnesses continue to occur, even in developed countries (Craun et al., 2010). Drinking water remains a potential source of microbial pathogens in the United States (Yoder et al., 2008) and other developed countries (Ngwenya et al., 2013) despite more than 40 years of improvements in treatment processes. Illnesses due to contaminated drinking water result in nearly one billion dollars annually in hospitalization costs alone in the U.S. (Hilborn et al., 2013).

The majority of drinking water-associated outbreaks in the U.S. in 2009-2010 were due to deficiencies in federally regulated portions of drinking water treatment plants (DWTPs) (Hilborn et al., 2013). Given this fact, few studies have evaluated drinking water treatment efficacy for microbial pathogens at DWTPs operating under real-world conditions. The Safe Drinking Water Act sets maximum contaminant levels (MCLs) or enforceable standards for some pathogens, which are published in the Code of Federal Regulations (CFR) under Title 40 CFR $§ 141$ subpart B (U.S. EPA, 2012). However many waterborne pathogens are unregulated. Monitoring directly for pathogens in treated drinking water is considered expensive and impractical, though it is recognized that monitoring for indicator bacteria (e.g. total and fecal coliforms, E. coli) is not useful for predicting the presence of non-fecally-related environmental pathogens. Systems using surface water or groundwater under the influence of surface water that serve $>10,000$ people are required to monitor for the human pathogen Cryptosporidium in source water used for drinking water (40 CFR $§ 141.700$; U.S. EPA, 2002a), as are systems serving < 10,000 people when $E$. coli levels exceed prescribed thresholds. To meet federal regulations, DWTPs use a 
variety of treatments to control levels of microorganisms, including filtration, chlorine $\left(\mathrm{Cl}_{2}\right)$, chloramine $\left(\mathrm{NH}_{2} \mathrm{Cl}\right)$, chlorine dioxide $\left(\mathrm{ClO}_{2}\right)$, ultraviolet light $(\mathrm{UV})$, and ozone $\left(\mathrm{O}_{3}\right)$.

A major gap exists in our understanding of the ecology of waterborne pathogens, including their occurrence and potential inactivation or removal during drinking water treatment. To begin to address this issue, this study was undertaken with the goal of obtaining occurrence information on microbial pathogens of known and emerging concern in source and treated drinking water. A secondary goal was to estimate removal, if any, of microbial pathogens from source waters by currently used drinking water treatment processes under typical plant operating conditions, and thus identify possible candidate organisms that may be amenable to enhanced reduction or removal. The occurrence of nine pathogens were estimated: two regulated protozoa, Cryptosporidium and Giardia, two bacteria listed on the U.S. Environmental Protection Agency's (USEPA) Contaminants Candidate List (U.S.EPA, 2015), Legionella pneumophila, and Mycobacterium avium, and other pathogens of concern including Aspergillus fumigatus, $A$. niger and A. terreus, M. avium subspecies paratuberculosis and M. intracellulare. Their occurrence was measured in paired source and treated water from 25 DWTPs located in 24 states across the U.S., representing small $(501-3,300$ people) to very large $(100,000+$ people $)$ systems using surface and/or groundwater and a variety of disinfection regimes. This paper is one of a series of related papers that comprise a national study that describes the presence, persistence, and concentration of emerging contaminants in drinking water. This paper focused specifically on microbial contaminants; the other papers in the series focus on the occurrence of chemical contaminants in source and treated drinking water. A comprehensive description of the national study can be found in this issue (Glassmeyer et al., 2016). 


\subsection{MATERIALS AND METHODS}

\subsection{Drinking Water Treatment Plant Selection}

DWTPs were nominated for inclusion in this study by field personnel from the U.S. Geological Survey (USGS). The final selection of DWTPs maximized geographical spread and represented a range of utility sizes and drinking water treatments. Table 1 describes basic information for each DWTP regarding population served, production volume, and simplified treatment train. A paired sampling scheme was designed to evaluate the treatment process with minimal potential for regrowth of microorganisms or contamination from biofilms in the distribution system.

\subsection{Sample Collection}

One source (prior to entering the DWTP) and one paired treated water sample were collected from each of 25 DWTPs in sterile $1 \mathrm{~L}$ sample bottles for all bacteria and fungi. Most of the DWTPs were plumbed with sampling taps at different locations in the plant. These taps allowed collection either directly, or from a tap in the facility's laboratory. The DWTPs were instructed to collect the source water sample prior to any treatment or settling basin. The treated water sample was collected at a sampling point after final disinfection but prior to the clear well. Approximately $10 \mathrm{~L}$ of source water were collected for protozoa analysis. One L of source and 1

$\mathrm{L}$ of treated water were collected for A. fumigatus, A. niger, and A. terreus analyses. Four L of source and $4 \mathrm{~L}$ of treated water in total were collected for L. pneumophila, M. avium, M. avium subspecies paratuberculosis, and M. intracellulare analyses. Samples were shipped to laboratories in coolers containing ice and kept at $4{ }^{\circ} \mathrm{C}$ until analysis. Shipping temperatures 
were monitored using an i-button (www.maximintegrated.com); shipping temperatures were on average less than $15^{\circ} \mathrm{C}$.

\subsection{Quantification of Cryptosporidium oocysts and Giardia cysts}

Only source water was sampled from 24 of 25 DWTPs (excluding DWTP 5) for Cryptosporidium and Giardia analyses. Samples were processed using a modified USEPA Method 1623 (US EPA, 2005). Briefly, 9-11 L were filtered in the field using the EnvirochekHV capsule (Pall-Gelman, Port Washington, NY,) using a flow meter. The last 250 $\mathrm{ml}$ of sample was not drained from the capsule. One sample used 2 capsules and only sampled 3.5 L because of clogging (DWTP 10). The outlet and then the inlet were capped and sent overnight on ice to the USEPA. Capsules were eluted as described in Method 1623 (US EPA, 2005). Immunomagnetic separation (IMS) was as described except heat dissociation was used (Ware et al., 2003). One IMS was performed per sample. Samples were stained using EasyStain (BTF Pty Ltd., North Ryde, NSW, Australia) as described by the manufacturer except all wash steps were omitted. Slides were then analyzed for Cryptosporidium oocysts and Giardia cysts and were enumerated as described in Method 1623 (US EPA, 2005).

\subsection{Detection of Aspergillus species using qPCR}

Methods and qPCR assays have been reported previously for detection of Aspergillus (Haugland et al., 2004). An aliquot of the DNA extracts, prepared according to Haugland et al. (2004), were used in this analysis. Five microliters of DNA extract, which was equivalent to 
analyzing $25 \mathrm{ml}$ of the original source or treated water sample, was analyzed per qPCR reaction. All primer and probe sequences used have been previously published (US EPA, 2002b).

Reactions were performed with thermal cycling conditions consisting of 2 min at $50^{\circ} \mathrm{C}, 10$ min at $95^{\circ} \mathrm{C}$, followed by 40 cycles of $15 \mathrm{sec}$ at $95^{\circ} \mathrm{C}$ for template denaturation and $1 \mathrm{~min}$ at $60^{\circ} \mathrm{C}$ for probe and primer annealing and primer extension. Quantification was based on standard curves generated for each microorganism. The detection limit for each assay was approximately one cell per qPCR reaction.

\subsection{Detection of $L$. pneumophila using qPCR}

Two assays were used to determine the presence of L. pneumophila in water samples. The Lp16S qPCR assay detects all L. pneumophila and the LpLPS assay detects serogroup 1 (SG1) strains of L. pneumophila only. Both assays have been previously described (Donohue et al., 2014). In general, $250 \mathrm{ml}$ to $2.5 \mathrm{~L}$ of each source water sample and $3 \mathrm{~L}$ of each treated water sample were filtered and DNA extracted using a modified WaterMaster ${ }^{\mathrm{TM}}$ (Epicentre Biotechnologies, Philadelphia, PA) DNA extraction protocol (Beumer et al., 2010).

All DNA extracts were analyzed using both qPCR assays (Lp16S and LpLPS). Reactions for the Lp16S assay and the LpLPS assay were performed in duplicate. Each reaction regardless of assay was performed with $5 \mu 1$ of DNA extract/template, which was equivalent to analyzing 8 to $80 \mathrm{ml}$ of the original source water sample or $100 \mathrm{ml}$ of the original treated water sample per qPCR reaction, using a Roche LightCycler® 480 II Real-time PCR system (Roche Applied Science, Indianapolis, IN). Formulations, instrument settings, and method for estimating quantities of L. pneumophila were performed as described in Donohue et al. (2014). A 
laboratory control, or lab blank (LB), which consisted of one filtrate of $100 \mathrm{ml}$ sterile molecular biology grade water per pair of source and treated water samples from each DWTP, was prepared at the same time and processed in an identical manner as samples. A sample was considered positive if the quantification cycle $(\mathrm{Cq})$ of both replicate $\mathrm{qPCR}$ reactions was $<40$. The detection limit for the Lp16S assay was approximately one target copy per qPCR reaction and 10 copies per qPCR reaction for the LpLPS assay.

\subsection{Detection of $M$. avium, M. intracellulare, and M. avium subsp. paratuberculosis using qPCR}

Characteristics of M. avium, M. avium subsp. paratuberculosis, and M. intracellulare $\mathrm{qPCR}$ assays have been described previously (Beumer et al., 2010; Chern et al., 2015). All three qPCR assays were performed on $10 \mu \mathrm{l}$ of DNA extract/template (the same extracts used for the Legionella qPCR assays), which was equivalent to analyzing 16 to $160 \mathrm{ml}$ of the original source water sample or $200 \mathrm{ml}$ of the original treated water sample per qPCR reaction, in triplicate. All reactions were carried out in an ABI Model 7900HT Sequence Detection System (Applied Biosystems, Foster City); calibration standards were run with every set of samples processed. An internal positive control (Applied Biosystems Exogenous Internal Positive Control) was added to every reaction to detect PCR inhibition. Positive qPCR assay controls included target DNA standards of known concentration. Negative qPCR assay controls included sterile $\mathrm{H}_{2} \mathrm{O}$ added to qPCR reaction rather than DNA template. A sample was considered positive if the quantification cycle $(\mathrm{Cq})$ of two of three replicate $\mathrm{qPCR}$ reactions was $<40$, and negative controls and LBs were negative (undetermined). The detection limits of the Mycobacterium qPCR assays were approximately 10 target copies per qPCR reaction for M. avium and $M$. 
intracellulare qPCR assays and 1.8 target copies per qPCR reaction for M. avium subspecies paratuberculosis assay.

Estimated quantities of mycobacteria were extrapolated from master standard curves as described in Beumer et al. (2010). A One-Way ANOVA (Kruskal-Wallis) using Sigma Plot version 12.5 (Systat Software, Inc., San Jose, CA) was performed to determine if differences in estimated quantities in source and treated water were significantly different $(\mathrm{p}<0.05)$.

\subsection{Culturing Mycobacteria}

Mycobacteria were cultured from source and treated water according to section 9260M of Standard Methods for the Examination of Water and Wastewater (Eaton et al., 2005), with modifications described in Covert et al. (1999). Two $500 \mathrm{ml}$ aliquots of treated water were not disinfected with cetyl pyridinium chloride (CPC) but filtered immediately as described for source water aliquots. Plates were incubated in plastic bags at $37{ }^{\circ} \mathrm{C}$ in a $10 \% \mathrm{CO}_{2}$ atmosphere for a minimum of 8 weeks and inspected weekly. Colonies that fit the morphologies described for mycobacteria in Glover et al. (1994) were selected for identification by bidirectional sequencing of the 16S rRNA gene. Putative identification of isolates was based on a minimum of $98 \%$ similarity to known $16 \mathrm{~S}$ rRNA sequences in the NCBI 16S rRNA database (http://www.ncbi.nlm.nih.gov). Twenty-three sequences were submitted to the National Center for Biotechnology Information and given GenBank Accession numbers KU686928 - KU686950.

\section{RESULTS}


In the current study, paired source and treated water samples were collected from 25 DWTPs across the U.S. The estimated concentration of each pathogen in source and treated water is provided, along with the limits of quantification for each method/assay, in Figure 1. No data from the molecular detection techniques were discarded due to the adverse effects of inhibition from the water matrix on a method/assay.

\subsection{Source Water}

All of the pathogens except M. avium subsp. paratuberculosis were detected in source water using molecular or culture methods, or microscopy for Cryptosporidium and Giardia (Table 2). A. fumigatus was detected in $48 \%(12 / 25)$ of source water samples, at a mean concentration of $1.4 \times 10^{1} \pm 7.0 \times 10^{0}$ cells/L. A. niger and A. terreus were detected in $20 \%$ $(5 / 25)\left(\overline{\boldsymbol{x}}=1.6 \times 10^{1} \pm 8.0 \times 10^{0}\right.$ cells/L) and $28 \%(7 / 25)\left(\overline{\boldsymbol{x}}=1.0 \times 10^{3} \pm 1.4 \times 10^{3}\right.$ cells/L $)$ of source water samples, respectively. Cryptosporidium were detected in 25\% (6/24) and Giardia in $46 \%(11 / 24)$ of the source water samples and their mean concentrations were $7.4 \times 10^{-1} \pm 2.7 \mathrm{x}$ $10^{-1}$ oocysts $/ \mathrm{L}$ and $8.4 \times 10^{-1} \pm 6.2 \times 10^{-1}$ cysts/L, respectively.

The lab blank (LB) associated with source and treated water from DWTP 3 was positive for L. pneumophila using the Lp16S qPCR assay and hence, data from this plant were excluded from the analysis (Table S1). L. pneumophila was present in $25 \%(6 / 24)$ of remaining source water samples (Figure 1) and had the highest concentration of any of the nine pathogens in water entering DWTPs $\left(\overline{\boldsymbol{x}}=2.2 \times 10^{4} \pm 4.3 \times 10^{4}\right.$ target copies/L). These samples were negative for $L$. pneumophila SG1 using the LpLPS qPCR assay. The LB associated with the source water from DWTP 4 was positive for all three species of mycobacteria and therefore data from that plant 
were excluded from the analysis (Table S1). No samples were deemed false negatives due to inhibition ( $\mathrm{Cq}$ values for the exogenous internal positive control were within the acceptable range). M. avium and $M$. intracellulare were detected by qPCR in $25 \%(6 / 24)$ of remaining source water samples $\left(\overline{\boldsymbol{x}}=2.2 \times 10^{4} \pm 3.1 \times 10^{4}\right.$ target copies $/ \mathrm{L}$ and $2.0 \times 10^{3} \pm 1.8 \times 10^{3}$ target copies/L, respectively). Both species were detected simultaneously at four DWTPs $(2,23,26$, and 28). M. avium, M. intracellulare, and M. avium subsp. paratuberculosis were not cultured from any source water samples. In most cases, culture plates from source water samples were too overgrown by faster growing bacteria or fungi to isolate slow-growing mycobacteria. The single source water sample to yield culturable mycobacteria was from DWTP 20, where a single isolate of $M$. fortuitum was obtained (Table 3). The total plate count for this sample was $>500$ $\mathrm{CFU} / \mathrm{ml}$ and the single isolate was plucked from the edge of a lawn of organisms growing on the plate.

The frequency of each pathogen's detection in source water ranked from highest to lowest was: A. fumigatus > Giardia > A. terreus > Cryptosporidium/ L. pneumophilal M. avium/ M. intracellulare $>$ A. niger. The mean concentration of each pathogen detected in source water ranked from highest to lowest: L. pneumophila $>$ M. avium $>$ M. intracellulare $>$ A. terreus $>$ A. niger $>$ A. fumigatus $>$ Giardia $>$ Cryptosporidium. Therefore, while fungal and protozoan pathogens were detected more frequently in source water samples than bacterial pathogens, the bacterial pathogens were present in higher concentrations.

\subsection{Treated Water}


The presence of seven pathogens (detected by qPCR) and culturable mycobacteria was determined in treated water obtained from the 25 DWTPs. Treatment, independent of method, reduced the populations of all three species of Aspergillus to below detection limits. $L$. pneumophila was detected in three treated water samples (DWTPs 4, 10, and 25) with the Lp16S assay, but only one sample (DWTP $10, \overline{\boldsymbol{x}}=3.0 \times 10^{3} \pm 0$ target copies/L) met acceptance criteria and was considered a true positive. This sample was negative for L. pneumophila SG1 (LpLPS assay).

The mycobacteria provide a more complex story. M. avium and M. intracellulare were detected in $24 \%(6 / 25)$ of treated waters by qPCR $\left(\overline{\boldsymbol{x}}=2.1 \times 10^{3} \pm 3.3 \times 10^{3}\right.$ target copies $/ \mathrm{L}$ and $8.0 \times 10^{2} \pm 1.4 \times 10^{3}$ target copies/L, respectively, Table 2). Both species were detected in treated water from six DWTPs $(1,10,20,26,27$, and 29). Additionally, M. avium subsp. paratuberculosis was detected by both IS900 and Target 251 qPCR assays in treated water from $13 \%$ (3/24) of DWTPs with a mean concentration of $4.8 \times 10^{2} \pm 4.7 \times 10^{2}$ target copies/L of the samples that were positive (Figure 1, Target 251 data not shown). Both $M$. intracellulare and $M$. avium subsp. paratuberculosis were detected at DWTP 4. M. avium subspecies paratuberculosis was not detected in any source water sample. Interestingly, there were four DWTPs where $M$. avium (DWTP 1, 20, 27, 29) or M. intracellulare (DWTP 4, 10, 20, 29) were detected in treated water but not source water.

As was true for source water, M. avium, M. intracellulare, and M. avium subsp. paratuberculosis were not cultured from treated water samples. However, five other species of pathogenic mycobacteria were isolated by culture and subsequently identified through $16 \mathrm{~S}$ rRNA sequence analysis from treated water obtained from three DWTPs (Table 3). Unlike the source water samples where overgrowth commonly occurred, the treated water samples produced very 
few colonies, with total plate counts ranging from 6 to $40 \mathrm{CFU} / 500 \mathrm{ml}$ (Table 2). Eight isolates of M. mucogenicum and one isolate of the closely-related $M$. phocaicum were obtained from DWTP 25, which utilized chloramine and ozonation disinfection. One isolate of M. fortuitum was obtained from treated water from DWTP 12, which used chlorination as a disinfectant. The treated water sample from DWTP 11 only produced six colonies, and all were sub-cultured for identification. Five isolates were putatively identified as $M$. lentiflavum and one isolate as $M$. triplex, both slow-growing mycobacteria. DWTP 11 used chlorine and ozonation disinfection. Finally, M. septicum was isolated from sand filter effluent obtained from DWTP 2, the only instance sand filter effluent was sampled.

There were 13 DWTPs where no pathogens (targeted in this study) were detected by molecular methods or by culture (mycobacteria) in treated water. One targeted pathogen was detected in three DWTPs while eight DWTPS had two pathogens detected. Only one DWTP had three pathogens detected in their treated water, and no DWTPs had four or more pathogens detected in treated water (Table 1, Supplementary Material).

\subsection{Effect of Drinking Water Treatment on Pathogens}

While Aspergillus were the most frequently detected pathogens in source water samples, they were never detected in treated water samples. Additionally, L. pneumophila (not SG1) was detected in source water samples from six DWTPs but was only detected in treated water from one DWTP. There were six DWTPs where M. avium was detected in source water. After treatment, the organism was reduced at two DWTPs and not detected at four DWTPs. In addition, there were six DWTPs where $M$. intracellulare was detected in source water. The 
organism was reduced by treatment at three of the DWTPs and not detected at the other three. At DWTPs where M. avium and M. intracellulare concentrations were reduced by treatment, the reduction was not statistically significant $(M$. avium, $\mathrm{P}=0.333 ;$ M. intracellulare, $\mathrm{P}=0.056)$. There were four DWTPs (M. avium and $M$. intracellulare) or three DWTPs (M. avium subsp. paratuberculosis) where mycobacteria were detected in treated water but not in source water by qPCR. Four DWTPs had no pathogens detected in either source or treated water (Table 1, Supplementary Material). Nine DWTPs demonstrated a complete reduction and eight DWTPs demonstrated a partial reduction in number of pathogens detected in treated water as compared to source water.

\section{DISCUSSION}

\subsection{Treatment for Control of Waterborne Pathogens}

The Interim Enhanced Surface Water Treatment Rule (U.S. EPA, 2002a), part of the Safe Drinking Water Act, requires DWTPs in the U.S. to treat for microbial contaminants using various treatment technologies and to maintain a disinfection residual in the finished water to prevent microbial growth during distribution (e.g. $0.2 \mathrm{mg} / \mathrm{L}$ free chlorine; 40 CFR $\$ 141$, subpart H). DWTPs commonly use chlorine, chloramine, chlorine dioxide, ozone, and ultraviolet light to meet drinking water standards for microbial contaminants. While several bench-scale studies have demonstrated the effectiveness of these disinfectants at controlling microbial contaminants (Sobsey et al., 1989), data are lacking on their effectiveness at DWTPs operating under realworld conditions. To address this issue, we conducted a small survey of source and treated water from 25 small to very large drinking water treatment plants (DWTPs) located in 24 states, using 
a variety of source water types and treatment technologies. Our results suggest that some pathogens are removed by treatment at these DWTPs but others are not.

\subsection{Occurrence of Cryptosporidium and Giardia in Source Water}

Several outbreaks of illness have been caused by Cryptosporidium in drinking water with the largest outbreak occurring in Milwaukee, Wisconsin in 1993 (MacKenzie et al., 1994). Treatment efficacy was not determined for protozoa in this study since only source water samples were analyzed as required under the USEPA's Long Term 2 Enhanced Surface Water Treatment Rule (LT2). Both Giardia and Cryptosporidium have unenforceable maximum contaminant level goals of zero, however, both are regulated by treatment technologies by either the Surface Water Treatment or the LT2 Rules. The low levels of Cryptosporidium and Giardia detected in source water samples in this study would presumably be removed by filtration and disinfection which has been demonstrated in several studies (Kelley et al., 1994; Jacangelo et al., 1995; Nieminski et al., 1995; Finch et al., 1997; Liyanage et al., 1997). Two large studies analyzing finished drinking water both using IMS based methodology report finding few

Cryptosporidium oocysts. A Cryptosporidium monitoring program from the UK in 2008 reports finding no water samples exceeded 1 oocyst/ 10L standard in over 50,000 samples examined (DWI, 2008). Rochelle et al. (2012) report no infectious oocysts in 370 samples analyzing 349,0593 L.

\subsection{Effect of Treatment on Aspergillus}

Filamentous fungi, like species of Aspergillus, are common heterotrophs in nature and it is typical to find them in water. In this study, Aspergillus species were detected by qPCR in $56 \%$ 
(14/25) of source water samples but none were detected in treated water. This is the first report describing efficacy of treatment for Aspergillus at DWTPs in the U.S. Though the number of DWTPs included in this study was small $(\mathrm{n}=25)$, Aspergillus species were detected in source water at 14 of the DWTPs. Those 14 DWTPs represent a range of production volumes (2.07 to 133 million gallons per day) using a variety of source water types and treatment regimes, and were geographically distributed (Table 1). It is a novel finding that various treatments are effective at removing Aspergillus from a diversity of waters. To our knowledge, this is the first report on the occurrence of Aspergillus at DWTPs in the U.S., though there are reports on the effect of treatment on Aspergillus in other parts of the world. Warris et al. (2003) recovered 34 isolates of A. fumigatus by culture from untreated lake water in Oslo, Norway, and 28 isolates post treatment. The DWTP used simple treatment including aeration, filtration, and chlorination, which was insufficient at removing this fungal species. Doggett (2000) detected multiple species of filamentous fungi, including Aspergillus, in distribution system biofilm obtained downstream from DWTPs in the U.S. They have also been detected in home taps (Vesper et al., 2007) and may gain access through leaks.

\subsection{Effect of Treatment on Legionella pneumophila}

During 2010 - 2012, the period during which samples were collected, 58\% of reported drinking-water associated outbreaks and 7\% of illnesses in the U.S. were due to Legionella (Hilborn et al., 2013). Legionella caused more reported drinking water outbreaks during that year than non-Legionella bacteria, protozoa, and viruses combined. QPCR was used to detect the presence of L. pneumophila in this study. This technique can detect DNA from live cells, viable but non-culturable cells, cells within amoebae, and dead cells. While detection of dead 
cells is a potential draw-back when estimating risk, qPCR detection of $L$. pneumophila provides information on the maximum levels in a sample, and is especially valuable when low levels are present, which are undetectable by culture (Donohue et al., 2014). L. pneumophila were detected in $25 \%(6 / 24)$ of source water samples and one treated water sample. The accuracy of the detection in treated water was confirmed on a separate portion of the same sample extracted for Mycobacterium qPCR analyses (data not shown). Though L. pneumophila SG1 cause most cases of Legionnaire's disease in the U.S., other serogroups of L. pneumophila and other species of Legionella are clinically significant in immunocompromised populations. In an international survey of isolates from patients with community-acquired legionellosis, only $12.8 \%$ of $L$. pneumophila isolates belonged to serogroups other than SG1 (Yu et al., 2002). Other species causing infection in the U.S. include L. micdadei, L. bozemanii, and L. dumoffii (Cunha et al., 2016).

DWTPs using chlorine disinfection $(\mathrm{n}=15)$ were negative for L. pneumophila in treated water. The DWTP which tested positive for $L$. pneumophila used monochloramine disinfection at the time of sampling. Several studies have suggested that monochloramine is an effective disinfectant for controlling free-living Legionella (Kool et al., 1999; Flannery et al., 2006; Moore et al., 2006; Heffelfinger et al., 2003). The effect of chloramine treatment on L. pneumophila is unclear from this study as the number of DWTPs using chloramine disinfection participating was small $(\mathrm{n}=10)$. The USEPA estimates that currently one in five individuals in the U.S. is supplied with chloramine-treated drinking water (U.S. EPA, 2009). Given the amount of illness associated with Legionella through drinking water, additional studies, much larger in scope, are needed to determine treatments most effective at inactivating Legionella under normal DWTP operating conditions. 


\subsection{Effect of Treatment on Mycobacteria}

The illnesses associated with M. avium and M. intracellulare, and M. avium subsp. paratuberculosis are well-known (WHO, 2004). M. avium, M. intracellulare, and M. avium subsp. paratuberculosis were detected in treated water from 6, 7, or 3 DWTPs, respectively, by qPCR, in this study. There were four instances that $M$. avium and $M$. intracellulare and three instances that M. avium subsp. paratuberculosis were detected in treated water but not source water by qPCR. This could result for several reasons. A smaller volume of source water was analyzed than treated water from most DWTPs by qPCR due to clogging of membrane filters. The hydrophobic outer membrane of mycobacteria causes clumping and a heterogeneous distribution of cells in aqueous environments (Anton et al., 1996), and only a single grab sample of source and treated water was collected from each DWTP. Detection of mycobacteria in treated but not source water could be due to their growth during treatment at the DWTP. Additional studies evaluating samples at various points in the treatment train at DWTPs would be necessary to test this hypothesis.

Mycobacteria were never recovered by culture from source water samples at DWTPs where they were recovered from treated samples. In fact, only one species of mycobacteria $(M$. fortuitum) was recovered by culture from a source water sample, though treated water from this plant was positive for both $M$. avium and $M$. intracellulare by $\mathrm{qPCR}$. M. fortuitum is a rapidly growing Mycobacterium species, requiring only three to four days to grow in culture. Due to extreme overgrowth, the culture plate from which it was isolated was removed from the incubator at two weeks of incubation. Isolation of $M$. avium and M. intracellulare requires a 
minimum of eight weeks incubation, which may explain why these species were not recovered from the source water sample by culture. Overgrowth of the medium by non-target microorganisms caused considerable loss of most source water samples prior to the minimum eight week incubation period required for the slow growing M. avium and M. intracellulare.

Five potentially pathogenic species of mycobacteria were cultured from treated water obtained from three DWTPs. M. mucogenicum and M. phocaicum are emerging pathogenic mycobacteria that are highly resistant to drinking water disinfection and are the etiologic agents of catheter-associated outbreaks in hospitals, as well as central nervous system, pulmonary, and skin/soft tissue infections in immunocompetent and compromised individuals (Adekambi, 2009). M. fortuitum is the most frequently isolated and clinically relevant species of the rapidly growing mycobacteria, and is recognized for causing wound, skin/soft tissue infections, and pulmonary disease (Ho et al., 2012). M. lentiflavum and M. triplex infections are rare; M. lentiflavum is associated with cervical lymphadenitis in children and both species have caused pulmonary disease (Piersimoni et al., 2004; Marshall et al., 2011). It is important to note that culturable mycobacteria were obtained from sample volumes equivalent to those analyzed when water is collected at the end of distribution $(500 \mathrm{ml})$. This study confirms that potentially pathogenic mycobacteria can be detected at the point of highest disinfection residual in DWTPs, independent of disinfectant type. DWTPs where mycobacteria were detected in treated water, either by qPCR or culture, were located in 11 geographically distributed states, used groundwater or surface water sources, and common drinking water disinfectants (chlorine, chloramine, chlorine dioxide, ozone, and ultraviolet light). Our findings are supported by laboratory studies demonstrating resistance of mycobacteria to frequently used drinking water disinfectants (Taylor et al., 2000). 
This paper is one in a collection of papers describing emerging chemical and microbial contaminants in source and treated drinking waters of the U.S. This portion of the study met the primary goal of providing information on the occurrence of known and emerging microbial contaminants for assessing the potential for human exposure to these contaminants from drinking water. This study also met the second goal of understanding the effect of treatment on emerging microbial contaminants under typical plant operating conditions. The study findings suggest that drinking water treatment is effective at inactivating potentially pathogenic species of Aspergillus. It remains unknown if chloramination is effective at inactivating $L$. pneumophila. In addition, mycobacteria belonging the Mycobacterium avium complex (e.g. M. avium, M. avium subsp. paratuberculosis, M. intracellulare) and other possible pathogenic species of mycobacteria were detected in water treated with various disinfectants. For pathogens that naturally inhabit water, like mycobacteria and Legionella, surviving drinking water treatment has serious implications for human health if they are able to amplify downstream of the DWTP to points of use where persons at risk may be exposed, either through ingestion, inhalation, or dermal contact. These findings suggest the need for additional research to identify the scope and magnitude of DWTP treatment efficacy with respect to Legionella and mycobacteria.

\section{ASSOCIATED CONTENT}

\section{Supplementary Material}

Supplemental Table 1. This material is available free of charge via the Internet at http://pubs.acs.org. 


\section{AUTHOR INFORMATION}

\section{Corresponding Author}

*Phone: 513-569-7893. Fax: 513-569-7757. Email: pfaller.stacy@epa.gov.

\section{Notes}

The authors declare no conflict of interest.

\section{ACKNOWLEDGEMENTS}

The authors declare no competing financial interest. The information in this document has been funded partially or wholly by the U.S. Environmental Protection Agency. The research described in this article has been funded in part by the U.S. Environmental Protection Agency through Interagency Agreement DW14922330 to the U.S. Geological Survey, and through programmatic support of the USGS Toxic Substances Hydrology Program and the USEPA's Office of Research and Development, Office of Water, Office of Chemical Safety and Pollution Prevention, and Region 8. Information Collection Rule approval for the Phase II Questionnaire was granted under USEPA ICR No. 2346.01, OMB Control No. 2080-0078. This manuscript has been subjected to review by the National Health and Environmental Effects Research Laboratory and approved for publication. Approval does not signify that the contents reflect the views of the USEPA and mention of trade names or commercial products does not constitute endorsement or recommendation for use by USEPA. This document has been reviewed in 
accordance with USGS policy and approved for publication. Any use of trade, firm, or product names is for descriptive purposes only and does not imply endorsement by the U.S.

Government. The authors would like to thank all participating DWTPs for their involvement in the project and for their assistance in collecting the samples. 


\section{REFERENCES}

Adekambi, T., 2009. Mycobacterium mucogenicum group infections: a review. Clin. Microbiol. Infect. $15,911-918$.

Anton, V., Rougé, P., Daffé, M., 1996. Identification of the sugars involved in mycobacterial cell aggregation. FEMS Microbiol. Lett. 144, 167-170.

Beumer, A., King, D., Donohue, M., Mistry, J., Covert, T., Pfaller, S., 2010. Detection of Mycobacterium avium subsp. paratuberculosis in drinking water and biofilms by quantitative PCR. Appl. Environ. Microbiol. 76, 7367-70.

Chern, E.C., King, D., Haugland, R., Pfaller, S., 2015. Evaluation of qPCR assays targeting Mycobacterium avium, Mycobacterium intracellulare and Mycobacterium avium subspecies paratuberculosis in drinking water biofilms. J. Water Health. 13.1, 131-139.

Covert, T. C., Rodgers, M. R., Reyes, A. L., Stelma, Jr., G. N., 1999. Occurrence of nontuberculous mycobacteria in environmental samples. Appl. Environ. Microbiol. 65, 24922496.

Craun, G. F., Brunkard, J. M., Yoder, J. S., Roberts, V. A., Carpenter, J., Wade, T., Calderon, R. L., Roberts, J. M., Beach, M. J., Roy, S. L., 2010. Causes of outbreaks associated with drinking water in the United States from 1971 to 2006. Clin. Microbiol. Rev. 23, 507-28.

Cunha, B. A., Burillo, A., Bouza, E., 2016. Legionaires' disease. Lancet 387, 376-385.

Doggett, M. S., 2000. Characterization of fungal biofilms within a municipal water distribution system. Appl. Environ. Microbiol. 66, 1249-51. 
Donohue, M. J., O’Connell, K., Vesper, S. J., Mistry, J. H., King, D., Kostich, M., Pfaller, S., 2014. Widespread molecular detection of Legionella pneumophila Serogroup 1 in cold water taps across the United States. Environ. Sci. Technol. 48, 3145-52.

Drinking Water Inspectorate (DWI). 2008. Drinking Water 2008.

http://www.dwi.gov.uk/about/annual-report/index.htm (accessed 16.02.09).

Eaton, A. D., Clesceri, L. S., Rice, E. W., Greenberg, A. E., 2005. Standard methods for the examination of water and wastewater, 21st ed., American Public Health Association, Washington, DC.

Finch, G. R., Gyurek, L. L., Liyanage, L. R. J., Belosevic, M., 1997. Effect of various disinfection methods on the inactivation of Cryptosporidium. Final Report, AWWARF, Denver, $\mathrm{CO}$.

Flannery, B., Gelling, L. B., Vugia, D. J., Weintraub, J. M., Salerno, J. J., Conroy, M. J., Stevens, V. A., Rose, C. E., Moore, M. R., Fields, B. S., Besser, R. E., 2006. Reducing Legionella colonization in water systems with monochloramine. Emerging Infect. Dis. 12, 588596.

Glassmeyer, S. T., Furlong, E. T., Kolpin, D. W., Batt, A. L., Benson, R., Boone, J. S., Conerly, O., Donohue, M. J., King, D. N., Kostich, M. S., Mash, H. E., Pfaller, S. L., Schenck, K. M., Simmons, J. E., Varughese, E. A., Vesper, S. J., Villegas, E. N., Wilson, V. S., 2016. Nationwide Reconnaissance of Contaminants of Emerging Concern in Source and Treated Drinking Waters of the United States. Sci. Total Environ., This issue. 
Glover, N., Holtzman, A., Aronson, T., Froman, S., Berlin, O. G., Dominguez, P., Kunkel, K. A., Overturf, G., Stelma, Jr., G. N., Smith, C., Yakrus, M., 1994. The isolation and identification of Mycobacterium avium complex (MAC) recovered from Los Angeles potable water, a possible source of infection in AIDS patients. Int. J. Environ. Health Res. 4, 63-72.

Haugland, R. A., Varma, M., Wymer, L. J., Vesper, S. J., 2004. Quantitative PCR of selected Aspergillus, Penicillium and Paecilomyces species. Syst. Appl. Microbiol. 27, 198-210.

Heffelfinger, J. D., Kool, J. L., Fridkin, S., Fraser, V. J., Hageman, J., Carpenter, J., Whitney, C. G., 2003. Risk of hospital-acquired Legionnaires' disease in cities using monochloramine versus other water disinfectants. Infect. Control Hosp. Epidemiol. 24, 569-574.

Hilborn, E. D., Wade, T. J., Hicks, L., Garrison, L., Carpenter, J., Adam, E., Mull, B., Yoder, J., Roberts, V., Gargano., J. W., 2013. Surveillance for waterborne disease outbreaks associated with drinking water and other nonrecreational water - United States, 2009-2010. MMWR Morb. Mortal. Wkly. Rep. 62, 714-720.

Ho, Y.S., Adroub, S.A., Aleisa, F., Mahmood, H., Othoum, G., Rashid, F., Zaher, M., Ali, S., Bitter, W., Pain, A., Abdallah, A. M., 2012. Complete genome sequence of Mycobacterium fortuitum subsp. fortuitum type strain DSM46621. J. Bacteriol. 194, 6337-8.

Jacangelo, J. G., Adham, S. S., Laine, J.-M., 1995. Mechanisms of Cryptosporidium, Giardia, and MS2 virus removal by microfiltration and ultrafiltration. J. AWWA 87, 107-121.

Kelley, M. B., Brokaw, J. K., Edzwalk, J. K., Fredericksen, D. W., Warrier, P. K., 1994. A survey of eastern U.S. Army installation drinking water sources and treatment systems for Giardia and Cryptosporidium. Proc. AWWA Wat. Qual. Tech. Conf., Denver, CO. 
Kool, J. L., Bergmire-Sweat, D., Butler, J. C., Brown, E. W., Peabody, D. J., Massi, D. S., Carpenter, J. C., Pruckler, J. M., Benson, R. F., Fields, B. S., 1999. Hospital characteristics associated with colonization of water systems by Legionella and risk of nosocomial Legionnaires' disease: a cohort study of 15 hospitals. Infect. Control Hosp. Epidemiol. 20, 798805.

Liyanage, L. R. J., Finch, G. R., Belosevic, M., 1997. Effect of aqueous chlorine and oxychlorine compounds on Cryptosporidium parvum oocysts. Environ. Sci. Technol. 31, 19921994.

MacKenzie, W. R., Hoxie, N. J., Proctor, M.E., Gradus, M. S., Blair, K. A., Peterson, D. E., Kazmierczak, J. J., Addiss, D. G., Fox, K. R., Rose, J. B., Davis, J. P., 1994. A massive outbreak in Milwaukee of Cryptosporidium infection transmitted through the public water supply. New Engl. J. Med. 331, 161-167.

Marshall, H. M., Carter, R., Torbey, M. J., Minion, S., Tolson, C., Sidjabat, H. E., Huygens, F., Hargreaves, M., Thomson, R.M., 2011. Mycobacterium lentiflavum in drinking water supplies, Australia. Emerg. Infect. Dis. 17, 395-402.

Moore, M. R., Pryor, M., Fields, B., Lucas, C., Phelan, M., Besser, R. E., 2006. Introduction of monochloramine into a municipal water system: impact on colonization of buildings by Legionella spp. Appl. Environ. Microbiol. 72, 378-383.

Ngwenya, N., Ncube, E. J., Parsons, J., 2013. Recent advances in drinking water disinfection: successes and challenges. Rev. Environ. Contam. Toxicol. 222, 111-70. Nieminski, E. C., Ongerth, J. E., 1995. Removing Giardia and Cryptosproridium by conventional treatment and direct filtration. J. AWWA 87, 96-106. 
Piersimoni, C., Goteri, G., Nista, D., Mariottini, A., Mazzarelli, G., Bornigia, S., 2004.

Mycobacterium lentiflavum as an emerging causative agent of cervical lymphadenitis. J. Clin.

Microbiol. 42, 3894-7.

Rochelle, P. A., Johnson, A. M., De Leon, R., Di Giovanni, G. D., 2012. Assessing the risk of infectious Cryptosporidium in drinking water. J. AWWA 104, 298-309.

Sobsey, M, D., 1989. Inactivation of health-related microorganisms in water by disinfection processes. Wat Sci Tech. 21, 179-195.

Taylor, R, H., Falkinham III, J. O., Norton, C. D., LeChavallier, M. W., 2000. Chlorine, chloramine, chlorine dioxide, and ozone susceptibility of Mycobacterium avium. Appl. Environ. Microbiol. 66, 1702-1705.

U.S. EPA, 2002a. Federal Register. Long Term 1 Enhanced Surface Water Treatment Rule, 67 FR1812, Vol. 67, No. 9.

U.S.EPA., 2002b. Identification and quantification of specific fungi and bacteria. US Patent No. $6,387,652$.

U.S.EPA, 2005. Method 1623: Giardia and Cryptosporidium in Water by Filtration/IMS/FA. No. EPA 815-R05-002. Washington, D.C.: United States Environmental Protection Agency, Office of Water.

U.S.EPA, 2009. Basic information about chloramines. https://www.epa.gov/sites/production/files/2015-09/documents/q2.pdf. (accessed 16.03.08). 
U.S.EPA., 2012. Code of Federal Regulations. Title 40, Protection of Environment. Part 141, National Primary Drinking Water Regulations. Subpart B, Maximum Contaminant Levels.

U.S. EPA., 2015. Federal Register. Drinking Water Contaminant Candidate List 4. 80 FR 6076, Vol. 80, No. 23.

Vesper, S. J., Rogers, M. E., Neely, A., Haugland, R. A., 2007. Opportunistic Aspergillus pathogens measured in home and hospital tap water by quantitative PCR (QPCR). J. Water Health 5, 427-431.

Ware, M. W., Wymer, L., Lindquist, H. D., Schaefer, 3rd, F. W., 2003. Evaluation of an alternative IMS dissociation procedure for use with Method 1622: detection of Cryptosporidium in water. J. Microbiol. Methods 55, 575-83.

Warris, A., Klaassen, C. H.W., Meis, J. F. G. M., de Ruiter, M. T., de Valk, H. A., Abrahamsen, P. G., Verweij, P. E., 2003. Molecular epidemiology of Aspergillus fumigatus isolates recovered from water, air, and patients shows two clusters of genetically distinct strains. J. Clin. Microbiol. $41,4101-4106$.

World Health Organization (WHO), 2004. Pathogenic mycobacteria in water: a guide to public health consequences, monitoring and management. Eds. Pedley, S.; Bartram, J.; Rees, G.;

Dufour, A.; Cotruvo, J. A. Int. Water Assoc., Geneva.

Yoder, J., Roberts, V., Craun, G. F., Hill, V., Hicks, L. A., Alexander, N. T., Radke, V., Calderon, R. L., Hlavsa, M. C., Beach, M. J., Roy, S. L., 2008. Surveillance for waterborne disease and outbreaks associated with drinking water and water not intended for drinking-United States, 2005-2006. MMWR Surveill. Summ. 57, 39-62.

Yu, V. L., Plouffe, J. F., Pastoris, M. C., Stout, J. E., Schousboe, M., Widmer, A., Summersgill, J., File, T., Heath, C. M., Paterson, D. L., Chereshsky, A., 2002. Distribution of Legionella 
species and serogroups isolated by culture in patients with sporadic community-acquired Legionellosis: an international collaborative survey. J. Infect. Dis. 186, 127-128. 


\section{Figure and Table Legends}

Figure 1. Estimated concentrations (per liter) of each target microorganism in source and treated water for each drinking water treatment plant listed in Table 1. The bold horizontal line on each graph indicates the limits of quantification for each assay, $A=1$ cell, $B=10$ copies, $C=1.8$ copies. Note that the y-axes differ.

Table 1. Population served, production volume, and type of treatment at each drinking water treatment plant.

Table 2. Percent detection of Cryptosporidium spp., Giardia, Legionella pneumophila, Aspergillus fumigatus, A. niger, A. terreus, Mycobacterium avium, $M$. intracellulare, and $M$. avium subsp. paratuberculosis in source and treated water samples.

Table 3. Drinking water treatment plants positive by culture for non-tuberculous mycobacteria, including water sample type (source or treated water), description of treatment train, \% similarity to $16 \mathrm{~S}$ rRNA of known mycobacteria, and total plate counts. 
Table 1. Population served, production volume, and type of treatment at each drinking water treatment plant.

\begin{tabular}{|c|c|c|c|c|c|}
\hline Location & $\begin{array}{c}\text { Pop } \\
\text { Served }^{\mathrm{a}} \\
(1000 \mathrm{~s})\end{array}$ & $\begin{array}{l}\text { Production } \\
\text { at } \\
\text { Sampling }^{\mathrm{a}} \\
\text { (MGD) }\end{array}$ & $\begin{array}{l}\text { Residence } \\
\text { Time of } \\
\text { Treatment }^{\mathrm{b}} \\
\text { (h) }\end{array}$ & $\begin{array}{c}\text { Primary } \\
\text { Disinfectant }^{\mathrm{c}}\end{array}$ & $\begin{array}{l}\text { Simplified } \\
\text { treatment } \\
\text { train }^{\mathrm{d}}\end{array}$ \\
\hline $\begin{array}{l}\text { DWTP } \\
1\end{array}$ & $>500$ & $>100$ & 10 & $\mathrm{O}_{3}+\mathrm{NH}_{2} \mathrm{Cl}$ & $\begin{array}{c}\mathrm{O}_{3}, \text { coag/floc, } \\
\mathrm{NH}_{2} \mathrm{Cl}, \mathrm{C}, \\
\text { floc, } \mathrm{C}, \mathrm{F}\end{array}$ \\
\hline $\begin{array}{l}\text { DWTP } \\
2\end{array}$ & $>500$ & $>100$ & 72 & $\mathrm{Cl}_{2}$ & $\begin{array}{c}\text { coag/floc, } \mathrm{S}, \\
\mathrm{SF}, \mathrm{GAC} \\
\mathrm{Cl}_{2}\end{array}$ \\
\hline $\begin{array}{l}\text { DWTP } \\
3\end{array}$ & $\begin{array}{l}50- \\
500\end{array}$ & $10-100$ & 6 & $\mathrm{Cl}_{2}+\mathrm{UV}$ & $\begin{array}{c}\text { coag/floc, C/ } \\
\mathrm{S}, \mathrm{F}, \mathrm{GAC} \\
\mathrm{Cl}_{2}, \mathrm{UV}\end{array}$ \\
\hline $\begin{array}{l}\text { DWTP } \\
4\end{array}$ & $>500$ & $10-100$ & 46 & $\mathrm{Cl}_{2}+\mathrm{NH}_{2} \mathrm{Cl}$ & $\begin{array}{c}\text { pre- } \mathrm{Cl}_{2}, \\
\text { coag/floc, } \mathrm{S} \text {, } \\
\text { secondary } \\
\mathrm{Cl}_{2}, \mathrm{SF}, \mathrm{NH}_{3}\end{array}$ \\
\hline $\begin{array}{l}\text { DWTP } \\
5\end{array}$ & $<50$ & $<10$ & 0.13 & $\mathrm{Cl}_{2}$ & $\mathrm{Cl}_{2}$ \\
\hline $\begin{array}{l}\text { DWTP } \\
10\end{array}$ & $\begin{array}{l}50- \\
500 \\
\end{array}$ & $>100$ & 7 & $\mathrm{NH}_{2} \mathrm{Cl}$ & $\begin{array}{c}\text { coag/floc ,S, } \\
\mathrm{NH}_{2} \mathrm{Cl}, \mathrm{F}\end{array}$ \\
\hline $\begin{array}{l}\text { DWTP } \\
11\end{array}$ & $<50$ & $<10$ & 7 & $\mathrm{O}_{3}+\mathrm{Cl}_{2}$ & $\begin{array}{l}\text { coag/floc, } \mathrm{S}, \\
\mathrm{C}, \mathrm{O}_{3}, \mathrm{GAC} \\
\text { and } \mathrm{SF}, \mathrm{Cl}_{2}\end{array}$ \\
\hline $\begin{array}{l}\text { DWTP } \\
12\end{array}$ & $<50$ & $<10$ & 30.72 & $\mathrm{Cl}_{2}$ & $\begin{array}{c}\text { coag/floc, } \\
\text { pre- } \mathrm{Cl}_{2}, \mathrm{C}, \\
\mathrm{GAC} \text { and } \mathrm{SF} \text {, } \\
\text { post- } \mathrm{Cl}_{2}\end{array}$ \\
\hline $\begin{array}{l}\text { DWTP } \\
13\end{array}$ & $>500$ & $>100$ & 1 & $\mathrm{Cl}_{2}$ & $\mathrm{Cl}_{2}$ \\
\hline $\begin{array}{l}\text { DWTP } \\
14\end{array}$ & $\begin{array}{l}50- \\
500\end{array}$ & $10-100$ & 10 & $\mathrm{ClO}_{2}+\mathrm{Cl}_{2}$ & $\begin{array}{c}\text { coag/floc, } \\
\text { pre- } \mathrm{ClO}_{2}, \\
\mathrm{GAC} \text { and } \mathrm{SF}, \\
\mathrm{Cl}_{2}\end{array}$ \\
\hline $\begin{array}{l}\text { DWTP } \\
15\end{array}$ & $<50$ & $<10$ & 1 & $\mathrm{Cl}_{2}$ & $\begin{array}{c}\text { coag/floc, } \mathrm{S}, \\
\mathrm{F}, \mathrm{Cl}_{2}\end{array}$ \\
\hline $\begin{array}{l}\text { DWTP } \\
16\end{array}$ & $\begin{array}{l}50- \\
500\end{array}$ & $10-100$ & 6 & $\mathrm{NH}_{2} \mathrm{Cl}$ & $\begin{array}{c}\text { coag/floc, } \mathrm{S}, \\
\text { GAC and SF, } \\
\mathrm{NH}_{2} \mathrm{Cl}\end{array}$ \\
\hline DWTP & $<50$ & $<10$ & 2 & $\mathrm{Cl}_{2}$ & C, coag/floc, \\
\hline
\end{tabular}




\begin{tabular}{|c|c|c|c|c|c|}
\hline 17 & & & & & $\begin{array}{c}\text { pre- } \mathrm{Cl}_{2}, \mathrm{~F}, \\
\mathrm{Cl}_{2}\end{array}$ \\
\hline $\begin{array}{l}\text { DWTP } \\
18\end{array}$ & $<50$ & $<10$ & 7.3 & $\mathrm{O}_{3}+\mathrm{NH}_{2} \mathrm{Cl}$ & $\begin{array}{c}\mathrm{O}_{3} \text {, floc, } \mathrm{S}, \\
\mathrm{Cl}_{2}, \mathrm{GAC} \text { and } \\
\mathrm{SF}, \mathrm{NH}_{2} \mathrm{Cl}\end{array}$ \\
\hline $\begin{array}{l}\text { DWTP } \\
19\end{array}$ & $\begin{array}{l}50- \\
500\end{array}$ & $10-100$ & 26 & $\mathrm{NH}_{2} \mathrm{Cl}$ & $\begin{array}{l}\text { coag/floc, } \\
\text { PAC, S, } \\
\text { ultrafiltration, } \\
\mathrm{NH}_{2} \mathrm{Cl} .\end{array}$ \\
\hline $\begin{array}{l}\text { DWTP } \\
20\end{array}$ & $>500$ & $10-100$ & 30 & $\mathrm{O}_{3}+\mathrm{Cl}_{2}$ & $\begin{array}{c}\text { floc, } \mathrm{S}, \mathrm{O}_{3}, \\
\text { GAC and SF, } \\
\mathrm{Cl}_{2}\end{array}$ \\
\hline $\begin{array}{l}\text { DWTP } \\
21\end{array}$ & $\begin{array}{l}50- \\
500\end{array}$ & $10-100$ & 90 & $\mathrm{Cl}_{2}$ & $\begin{array}{l}\text { PAC pre- } \mathrm{Cl}_{2}, \\
\text { coag, } \mathrm{S}, \mathrm{Cl}_{2}, \\
\mathrm{~F}\end{array}$ \\
\hline $\begin{array}{l}\text { DWTP } \\
22\end{array}$ & $\begin{array}{l}50- \\
500\end{array}$ & $10-100$ & 10 & $\begin{array}{c}\mathrm{O}_{3}+\mathrm{Cl}_{2}+ \\
\mathrm{UV}\end{array}$ & $\begin{array}{c}\text { pre- } \mathrm{O}_{3} \text {, coag, } \\
\mathrm{S}, \mathrm{O}_{3}, \mathrm{GAC} \\
\text { and } \mathrm{SF}, \mathrm{UV}, \\
\mathrm{Cl}_{2}\end{array}$ \\
\hline $\begin{array}{l}\text { DWTP } \\
23\end{array}$ & $\begin{array}{l}50- \\
500\end{array}$ & $10-100$ & 7 & $\begin{array}{c}\mathrm{ClO}_{2}+\mathrm{UV}+ \\
\mathrm{Cl}\end{array}$ & $\begin{array}{c}\text { pre-ClO } \\
\text { coag/floc, } \mathrm{S}, \\
\text { dual media } \mathrm{F}, \\
\mathrm{UV}, \mathrm{Cl}_{2}\end{array}$ \\
\hline $\begin{array}{l}\text { DWTP } \\
24\end{array}$ & $\begin{array}{l}50- \\
500\end{array}$ & $10-100$ & 8 & $\mathrm{NH}_{2} \mathrm{Cl}$ & $\begin{array}{c}\mathrm{PAC}, \mathrm{GAC} \\
\text { and } \mathrm{SF}, \\
\mathrm{NH}_{2} \mathrm{Cl}\end{array}$ \\
\hline $\begin{array}{l}\text { DWTP } \\
25\end{array}$ & $\begin{array}{l}50- \\
500\end{array}$ & $10-100$ & 13.6 & $\mathrm{O}_{3}+\mathrm{NH}_{2} \mathrm{Cl}$ & $\begin{array}{c}\text { Pre- } \mathrm{O}_{3} \text {, coag, } \\
\mathrm{NH}_{2} \mathrm{Cl}\end{array}$ \\
\hline $\begin{array}{l}\text { DWTP } \\
26\end{array}$ & $\begin{array}{l}50- \\
500\end{array}$ & $10-100$ & $24-36$ & $\mathrm{Cl}_{2}$ & $\begin{array}{c}\text { pre- } \mathrm{Cl}_{2}, \\
\text { PAC, coag, } \\
\mathrm{S}, \mathrm{Cl}_{2}, \mathrm{~F}, \mathrm{Cl}_{2}\end{array}$ \\
\hline $\begin{array}{l}\text { DWTP } \\
27\end{array}$ & $\begin{array}{l}50- \\
500\end{array}$ & $<10$ & 4 & $\begin{array}{c}\mathrm{NH}_{2} \mathrm{Cl}+ \\
\mathrm{UV}\end{array}$ & $\begin{array}{c}\text { PAC, } \\
\text { coag/floc, S, } \\
\text { F, UV, } \\
\mathrm{NH}_{2} \mathrm{Cl}\end{array}$ \\
\hline $\begin{array}{l}\text { DWTP } \\
28\end{array}$ & $>500$ & $>100$ & 1 & $\mathrm{O}_{3}+\mathrm{NH}_{2} \mathrm{Cl}$ & $\mathrm{NH}_{2} \mathrm{Cl}, \mathrm{O}_{3}, \mathrm{~F}$ \\
\hline $\begin{array}{l}\text { DWTP } \\
29\end{array}$ & $<50$ & $<10$ & 8 & $\mathrm{Cl}_{2}$ & $\begin{array}{c}\text { PAC, pre- } \\
\mathrm{Cl}_{2}, \\
\text { coag/floc, S, } \\
\mathrm{Cl}_{2}, \mathrm{~F} \\
\end{array}$ \\
\hline
\end{tabular}


${ }^{a}$ Population sizes binned to give indication of drinking water treatment plant (DWTP) size variation while maintaining plant anonymity. $\mathrm{MGD}=$ million gallons per day.

${ }^{b}$ DWTPs were asked to match the residence time of treatment. Some locations achieved this better than others. DWTP = drinking water treatment plant;

${ }^{\mathrm{c}} \mathrm{O}_{3}=$ ozone; $\mathrm{NH}_{2} \mathrm{Cl}=$ chloramine; $\mathrm{Cl}_{2}=$ chlorine; $\mathrm{UV}=$ ultraviolet radiation; $\mathrm{ClO}_{2}=$ chlorine dioxide.

${ }^{\mathrm{d}}$ Major steps in treatment in each plant. Coag= coagulation; floc= flocculation; $\mathrm{C}=$ clarification; $\mathrm{F}=$ filtration; $\mathrm{S}=$ sedimentation; $\mathrm{SF}=$ sand filter; $\mathrm{PAC}=$ powdered activated carbon; $\mathrm{GAC}=$ granular activated carbon. 
Table 2. Percent detection of Cryptosporidium spp., Giardia, Legionella pneumophila, Aspergillus fumigatus, A. niger, A. terreus, Mycobacterium avium, M. intracellulare, and M. avium subsp. paratuberculosis in source and treated water samples.

\begin{tabular}{|c|c|c|c|c|c|c|}
\hline \multirow[t]{2}{*}{ Target } & \multicolumn{3}{|c|}{ Source Water } & \multicolumn{3}{|c|}{ Treated Water } \\
\hline & $\%$ Detect & Mean of Positives & Median of Positives & $\%$ Detect & Mean of Positives & Median of Positives \\
\hline $\begin{array}{c}\text { Cryptosporidium spp. } \\
\text { (oocysts/L) }\end{array}$ & 25 & $7.4 \times 10^{-1}$ & $7.6 \times 10^{-1}$ & Not sampled & & \\
\hline $\begin{array}{c}\text { Giardia } \\
\text { (cysts/L) }\end{array}$ & 46 & $8.4 \times 10^{-1}$ & $7.3 \times 10^{-1}$ & Not sampled & & \\
\hline $\begin{array}{l}\text { L. pneumophila } \\
\text { (target copy/L) }\end{array}$ & 25 & $2.2 \times 10^{4}$ & $4.1 \times 10^{3}$ & 4 & $3.0 \times 10^{3}$ & $3.0 \times 10^{3}$ \\
\hline $\begin{array}{l}\text { A. fumigatus } \\
\text { (cells/L) }\end{array}$ & 48 & $1.4 \times 10^{1}$ & $1.00 \times 10^{1}$ & 0 & $<$ limit of detection & $<$ limit of detection \\
\hline $\begin{array}{c}\text { A. terreus } \\
\text { (cells/L) }\end{array}$ & 28 & $8.9 \times 10^{2}$ & $2.50 \times 10^{2}$ & 0 & $<$ limit of detection & $<$ limit of detection \\
\hline $\begin{array}{l}\text { A. niger } \\
\text { (cells/L) }\end{array}$ & 20 & $1.6 \times 10^{1}$ & $1.00 \times 10^{1}$ & 0 & $<$ limit of detection & $<$ limit of detection \\
\hline $\begin{array}{c}\text { M. avium } \\
\text { (target copy/L) }\end{array}$ & 24 & $2.2 \times 10^{4}$ & $6.99 \times 10^{3}$ & 25 & $2.1 \times 10^{3}$ & $6.9 \times 10^{2}$ \\
\hline $\begin{array}{l}\text { M. intracellulare } \\
\text { (target copy/L) }\end{array}$ & 25 & $2.0 \times 10^{3}$ & $1.69 \times 10^{3}$ & 25 & $8.0 \times 10^{2}$ & $2.1 \times 10^{2}$ \\
\hline $\begin{array}{l}\text { M. avium subsp. } \\
\text { paratuberculosis } \\
\text { (target copy/L) }\end{array}$ & 0 & $<$ limit of detection & $<$ limit of detection & 8 & $4.8 \times 10^{2}$ & $8.6 \times 10^{0}$ \\
\hline
\end{tabular}


Table 3. Drinking water treatment plants positive by culture for non-tuberculous mycobacteria, including water sample type (source or treated water), description of treatment train, $\%$ similarity to $16 \mathrm{~S}$ rRNA of known mycobacteria, and total plate counts.

\begin{tabular}{|c|c|c|c|c|c|c|}
\hline DWTP $^{\mathrm{a}}$ & $\begin{array}{c}\text { Source } \\
\text { Water Type }\end{array}$ & $\begin{array}{c}\text { Water } \\
\text { Sample } \\
\text { Type }\end{array}$ & $\begin{array}{c}\text { Simplified Treatment } \\
\text { Train }^{\mathrm{c}}\end{array}$ & $\begin{array}{c}\text { Putative } \\
\text { Identification } \\
\text { (No. of } \\
\text { Isolates } \\
\text { Obtained) }\end{array}$ & $\begin{array}{l}\text { \% Similarity } \\
\text { to 16S rRNA } \\
\text { (GenBank }^{d} \\
\text { Accession } \\
\text { Number) }\end{array}$ & $\begin{array}{c}\text { Total CFU/Vol } \\
\text { Filtered }^{\mathrm{e}}\end{array}$ \\
\hline $\begin{array}{l}\text { DWTP } \\
2\end{array}$ & $\begin{array}{l}\text { Surface } \\
\text { water }\end{array}$ & $\begin{array}{c}\text { Sand } \\
\text { filter } \\
\text { effluent }^{\text {b }}\end{array}$ & $\begin{array}{l}\text { Coagulation/flocculation, } \\
\text { sedimentation, sand } \\
\text { filtration, GAC, } \\
\text { chlorination }\end{array}$ & $\begin{array}{c}\text { M. septicum } \\
\text { (7) }\end{array}$ & $\begin{array}{c}99 \% \\
(\mathrm{NR} 042916.1)\end{array}$ & TNTC $^{\mathrm{f}} / 500 \mathrm{ml}$ \\
\hline $\begin{array}{l}\text { DWTP } \\
11\end{array}$ & $\begin{array}{l}\text { Surface } \\
\text { water }\end{array}$ & $\begin{array}{l}\text { Treated } \\
\text { water }\end{array}$ & $\begin{array}{l}\text { Coagulation/flocculation, } \\
\text { sedimentation, } \\
\text { clarification, ozone, } \\
\text { GAC, sand filtration, } \\
\text { chlorination }\end{array}$ & $\begin{array}{c}M . \\
\text { lentiflavum } \\
\text { (5) } \\
\text { M. triplex } \\
\text { (1) }\end{array}$ & $\begin{array}{c}98-99 \% \\
(\mathrm{NR} 041898.1) \\
99 \% \\
\text { (GQ153279.1) }\end{array}$ & $6 \mathrm{CFU} / 500 \mathrm{ml}$ \\
\hline DWTP & Groundwater & Treated & Coagulation/flocculation, & M. fortuitum & $98 \%$ & $12 \mathrm{CFU} / 500 \mathrm{ml}$ \\
\hline
\end{tabular}




\begin{tabular}{|c|c|c|c|c|c|c|}
\hline 12 & $\begin{array}{l}\text { Under the } \\
\text { Influence of } \\
\text { Surface } \\
\text { Water }\end{array}$ & water & $\begin{array}{l}\text { pre-chlorination, GAC, } \\
\text { sand filtration, post- } \\
\text { chlorination }\end{array}$ & (1) & (AF480580.1) & \\
\hline $\begin{array}{c}\text { DWTP } \\
25\end{array}$ & $\begin{array}{c}\text { Surface } \\
\text { water }\end{array}$ & $\begin{array}{c}\text { Treated } \\
\text { water }\end{array}$ & $\begin{array}{l}\text { Pre-ozonation, } \\
\text { coagulation, } \\
\text { chloramination }\end{array}$ & $\begin{array}{c}\text { M. } \\
\text { mucogenicum } \\
\text { (8) } \\
\text { M. phocaicum } \\
\text { (1) }\end{array}$ & $\begin{array}{c}98-99 \% \\
(\mathrm{AY} 457075.1) \\
99 \% \\
(\mathrm{HQ} 845985.1)\end{array}$ & $40 \mathrm{CFU} / 500 \mathrm{ml}$ \\
\hline $\begin{array}{c}\text { DWTP } \\
20\end{array}$ & $\begin{array}{c}\text { Surface } \\
\text { water }\end{array}$ & $\begin{array}{l}\text { Source } \\
\text { water }\end{array}$ & $\begin{array}{l}\text { Coagulation/flocculation, } \\
\text { PAC, sedimentation, } \\
\text { ultrafiltration, } \\
\text { chloramination }\end{array}$ & $\begin{array}{c}\text { M. fortuitum } \\
\text { (1) }\end{array}$ & $\begin{array}{c}98 \% \\
(\mathrm{GU} 142933.1)\end{array}$ & TNTC/30 ml \\
\hline
\end{tabular}

${ }^{\text {a } D e t a i l e d ~ d e s c r i p t i o n s ~ o f ~ d r i n k i n g ~ w a t e r ~ t r e a t m e n t ~ p l a n t s ~(D W T P s) ~ c a n ~ b e ~ f o u n d ~ i n ~ G l a s s m e y e r ~ e t ~ a l ., ~ t h i s ~ i s s u e . ~}$

${ }^{\mathrm{b}}$ The only sand filter effluent sample in this study, obtained mid-way through treatment train and not disinfected.

${ }^{\mathrm{c}}$ For a complete description of treatment trains, see Glassmeyer et al., this issue.

${ }^{\mathrm{d}}$ GenBank = NIH genetic sequence database (Nucleic Acids Research, 2013 Jan;41(D1):D36-42).

${ }^{\mathrm{e}} \mathrm{CFU}=$ colony forming units/volume water filtered. The volume of source water filtered varied due to clogging, and 
was typically less than treated water.

${ }^{\mathrm{f}} \mathrm{TNTC}=$ too numerous to count $(>500 \mathrm{CFU})$. 

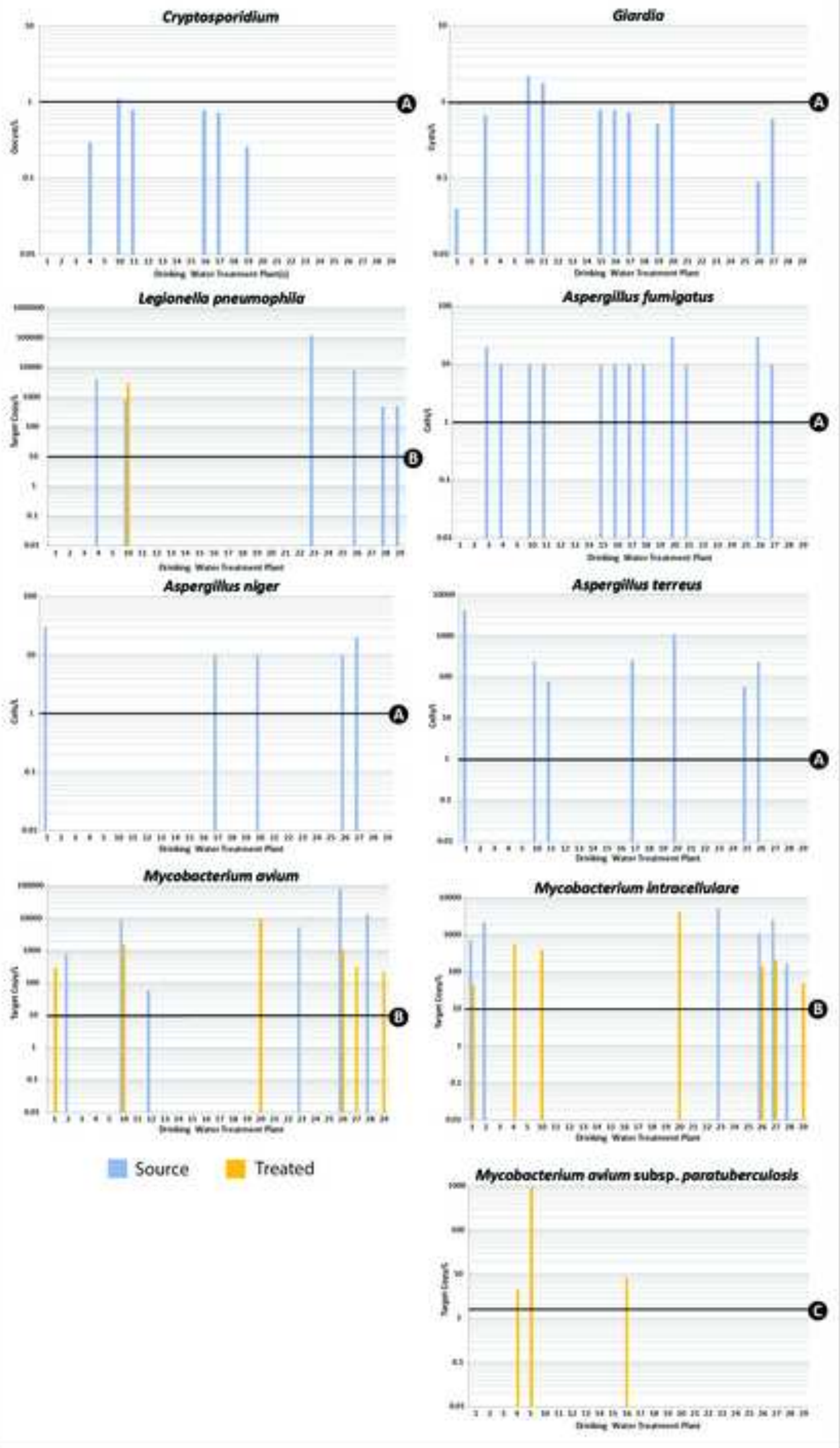
Nine pathogens measured in source waters and treated drinking waters

from 25 treatment plants across the US.

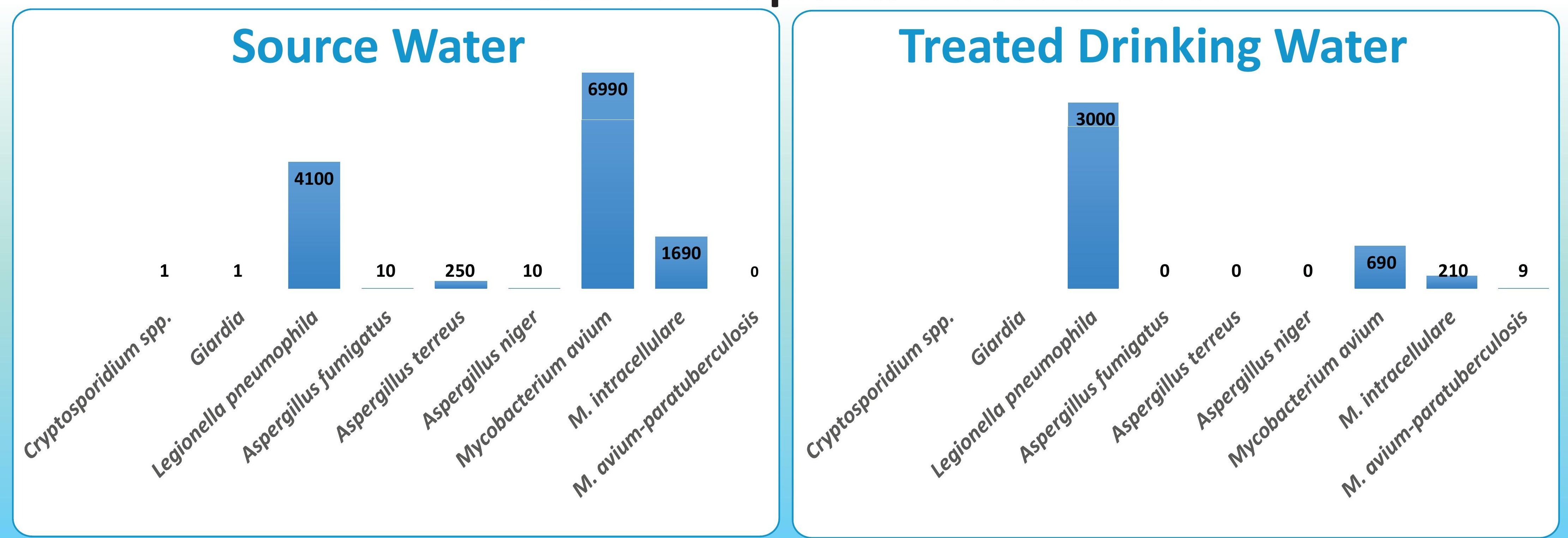

